\title{
PENGANIAYAAN BERAT SEBAGAI ALASAN PENGHALANG MEWARISI DALAM KOMPILASI HUKUM ISLAM PASAL 173 HURUF A
}

\author{
Riyan Ramdani, M. Najib Karim \\ Prodi Hukum Keluarga Prodi Hukum Keluarga \\ E-mail: riyannramdani@uinsgd.ac.id,najibcreator26@gmail.com
}

\begin{abstract}
The purpose of this study was to explore severe persecution as the reason the barrier inherits in a compilation of Islamic law section 173 the letter A. the topic of "Severe Persecution" isan interesting topic both academic and general quarters about it can be highlighted in both the book and the legacy. Nextaya persecution heavy is the new form of inherited law Indonesia included in a compilation of Islamic law under section 173 of the lette $A$ the view of cleric 4 of madzhab category of severe persecution is not through research. Using the yuridis normative and yuridis empiris method in the form of content analysis. After heavy mayhem is categorized as the reason for the obstacle inheriting acquired knowledge and understanding the data is then analyzed comprehensive to find the basis of his KHI's law makes the persecution tough as an excuse for inheritable rule, the istinbath of KHI chapter 173 of the relationship between section 173 and the opinions of Indonesian scholars. The study found a result in a compilation of Islam law not given a clear, concrete understanding of what constitutes severe persecution. The priest hanafi argued that murder was not entitled to an inheritance by the one whom he killed whether intentionally or imbued, and then in this context the combination of Islamic law used the three methods of ushul figh in determining the renewal of the barrier, first, maslahah mursalah, second, sad dzariah, third, qiyas. And interrelated to the scholars' opinion that a grouping of heiress in KHI chapter 173 is a legal renewal of heiress according to the code "law can change accourding to the circumstances.
\end{abstract}

Keywords: Severe persecution, Islamic inheritance law, Compilation of Islamic Law chapter 173 letter A

\begin{abstract}
Abstrak
Penelitian ini bertujuan untuk mengeksplorasi penganiayaan berat sebagai alasan penghalang mewarisi dalam Kompilasi Hukum Islam pasal 173 huruf A. Topik mengenai "penganiayaan berat" merupakan topik menarik dikalangan akademik maupun dikalangan umum. Diskursus mengenai hal tersebut dapat disorot dari aspek hukum maupun kewarisan. Selanjutnya penganiayaan berat merupakan bentuk pembaharuan hukum kewarisan di Indonesia yang termaktub dalam Kompilasi Hukum Islam Pasal 173 huruf A sedangkan dalam pandangan Ulama 4 madzhab kategori penganiayaan berat tidak termasuk dalam pandangan para Ulama. Data penelitian ini diperoleh melalui penelitian yang menggunakan metode yuridis normatif dan yuridis empiris dengan bentuk content analysis. Setelah konsep penganiayaan berat yang dikategorikan sebagai alasan penghalang mewarisi dipelajari dan di fahami, data kemudian dianalisa secara
\end{abstract}


komprehensif untuk menemukan dasar hukum KHI menjadikan penganiayaan berat sebagai alasan penghalang mewarisi, proses istinbath hukum KHI pasal 173 dan Hubungan antara pasal 173 dengan pendapat para Ulama Indonesia. Penelitian ini menemukan sebuah hasil Dalam Kompilasi Hukum Islam tidak diberikan pengertian yang jelas dan konkret tentang apa yang dimaksud dengan penganiayaan berat. Imam Hanafi berpendapat bahwasanya pembunuhan tidak berhak mendapatkan warisan dari seseorag yang ia bunuh baik dibunuh secara sengaja atau tidak sengaja, kemudian Dalam konteks ini Kompilasi Hukum Islam menggunakan tiga metode ushul fiqh dalam menentukan pembaharuan penghalang kewarisan, pertama, maslahah mursalah, kedua, sad dzariah, ketiga, qiyas. Dan Hubungan antar pasal dengan pendapat para ulama bahwasanya pengelompokkan penghalang waris dalam KHI pasal 173 adalah pembaharuan hukum waris sesuai dari sebuah kaidah "Hukum bisa berubah sesuai dengan keadaan tempat dan waktu"

Kata-kata Kunci: Penganiayaan Berat, Hukum Waris Islam, Kompilasi Hukum Islam Pasal 173 Huruf A

\section{PENDAHULUAN}

Satu bagian komponen yang terpenting dalam hukum positif di Indonesia ialah Hukum Islam.Karena merupakan salah satu bagian hukum yang menjadi bagian dari hukum Islam ialah hukum kewarisan.Permasalahan kompleksitas dalam hukum perkara perdata karena alsan untuk mendapatkan harta ialah warisan.Hal ini bersangkutan degan harta benda seseorang dan hukum personal.

Hukum kewarisan pada dasarnya Islam secara keseluruhan. Hukum kewarisan merupakan terjemahan dari fiqh mawaris yang berarti berpindahnya harta orang yang wafat kepada orang yang masih hidup.Pembagian itu lazim disebut ilmu faraidh (dalam bahasa arab) yaitu semua yang berhal menerima bagian tertentu yang dibagi menurut agama islam. ${ }^{1}$

Proses pemindahan harta terlaksana apabila beberapa unsurnya terpenuhi. Adapun beberapa unsurnya: 1. Ada Pewaris, 2.Harta Warisan, 3.Ahli Waris.

Hijab waris/mani' merupakan gugurnya hak seseorang untuk mewarisi peninggalan harta dikarenakan keberadaan penghalang. Namun, tidak adanya penghalang tidak berarti seseorang diberikan hak waris. Dengan maksud lain, terhalangnya waris adalah perbuatan setelah adanya sebab-sebab diwaris yang digunakan diwariskannya harta peninggalan oleh seseorang. ${ }^{2}$

Diantar penghalang kewarisan yang disepakati dalam hukum waris Islam teradapat tiga (3) jenis: perbudakan, pembunuhan dan berlainan agama. Perlahan mulai

\footnotetext{
${ }^{1}$ Beni Ahmad Saebani, Fiqh Mawaris, 1st ed (Bandung:CV.Pustaka Setia,209),hlm. 13.

${ }^{2}$ Komite Fakultas Syari'ah Al-Azhar Mesir, 'Ahkam Al-Mawarits Fi Al-Fighi Al-Islam, Diterjemahkan Addys Aldiar, Faturrahma. Hukum Waris,(Jakarta:Senayan Abadi Publishing,2004),hlm. 30.
}

98 Al-Ahwal Al-Syakhsiyyah : Jurnal Hukum dan Peradilan Islam 
berubah sejalan untuk dipercepatnya mendapatkan harta warisan dari pewarisnya sesuai dengan laju perubahan, ada yang dengan melakukan tindak pidana penganiayaan kepada ahli warisnya, memfitnah ahli waris dan lain sebagainya, seseorang tidak lagi melakukan dengan tindak pidana pembunuhan.Adanya pembahasan lebih lanjut adanya ketentuan semacam ini, mengingat fiqh madzhab tidak dicantumkan ketentuan tersebut sebagai penghalang kewarisan dalam produk hukum Islam.

Ditinjau dari kacamata kemanusiaan, perbuatan penganiayaan, memfitnah terhadap ahli waris merupakan tindakan yang tidak manusiawi dan membahayakan keadaan seseorang walau diperbaharuinya kebutuhan umat Islam di Indonesia berupa produk hukum yang baru karena adanya niat untuk mempercepat seseorang mendapatkan harta warisan.

Adanya pembaharuan hukum Islam di Indonseia, terkhusus didalam Kompilasi Hukum Islam pada buku ke II yang menerangkan tentang kewarisan terdiri daripada 6 bab dan 44 pasal sebagai naungan hakim di bawah naungan Peradilan Agama. Adapun pasal 173 menyatakan bahwa seseorang terhalang menjadi ahliwaris dari pewarisnya dengan keputusan hakim yang mempunyai kekuatan hukum tetap di hukum:

Seseorang terhalang menjadi ahli waris apabila dengan putusan hakim yang telah mempunyai kekuatan hukum yang telah, dihukum karena : a) Dipersalahkan telah membunuh atau mencoba membunuh atau menganiaya berat pada pewaris, b) Dipersalahkan secara memfitnah telah mengajukan pengaduan bahwa pewaris telah melakukan kejahatan yang di ancam dengan hukuman lima tahun penjara atau hukuman yang lebih berat ${ }^{3}$.

Bila membandingkan kepada dasar hukum kewarisan yang tertera pada alQuran dan Sunnah tampak adaya perbedaan yang cukup mendasar.Perbedaan terebut ialah terdapat pda ayat a dan $b$ yang mencantumkan perilaku fitnah, mencoba membunuh dan penganiayaan berat sebagai alasan terhalangnya hak mendapatkan waris dari ahli waris dalam pasal 173 Kompilasi Hukum Islam.Ketentuan hukum pada waris diambil daripada dasar hukum ketentuan alQuran dan Hadits, ketiga penghalang kewarisan; 1.Percobaan pembunuhan, 2.Penganiayaan Berat dan 3.Fitnah tidak terdapat dalam redaksi alQuran, Hadits maupun dalam bahasan fiqh sebagai penghalang waris. Ketiga penghalang yang terdapat dalam KHI juga terlihat bertentangan dengan salah satu faktor kewariasn yaitu pewaris. ${ }^{4}$.

Dinyatakan pembunuhan dalam kategori penghalang kewarisan huruf a sejalan dengan aturan hukum kewarisan Islam yang bersumber dari hujjah yang sahih, namun dijadikannya percobaan pembunuhan, penganiayaan berat dan fitnah sebagai penghalang mewarisi merupakan ketentuan baru yang terdapat dalam KHI. Bila dicermati ketiga

\footnotetext{
${ }^{3}$ Undang-Undang Republik Indonesia Nomor 1 Tahun 1974 Tentang Perkawinan dan Kompilasi Hukum Islam, $2^{\text {nd }}$ ed (Yogyakarta:Pustaka Yustisia,2009),hlm. 19.

${ }^{4}$ Hajar M,Dimensi Hukum Kewarisan Islam di Indonesia, $1^{\text {st }}$ ed (Pekanbaru,2008),hlm. 111.
} 
kategori penghalang kewarisan ini, pewaris berarti belum meninggal dunia ${ }^{5}$. Sedangkan hakikat berpindahnya harta dari pewaris kepada ahli waris apabila pewaris telah meninggal. Pada percobaan pembunuhan dan penganiayaan pewaris disiksa langsung oleh calon waris, dan terdapat memfitnah pewaris dalam putusan Hakim pengadilan dengan tuduhan palsu calon ahli waris ${ }^{6}$.

Berdasarkan uraian diatas, penganiayaan berat merupakan ketentuan baru yang terdapat dalam KHI.. Oleh karena itu, dalam tulisan ini akan dikaji dasar hukum Kompilasi Hukum Islam (KHI) menjadikan penganiayaan berat sebagai alaasan penghalang mewarisi, proses istinbath hukumKompilasi Hukum Islam pasal 173, dan hubungan antara pasal 173 dengan pendapat para ulama.

\section{METODOLOGI}

Penelitian ini berupa penelitian yuridis normatif dan yuridis empiris berbentuk content analysis yang bersifat kualitatif, yaitu penyelidikan kepustakaan dengan mengumpulkan data yang dibutuhkan melalui telaah terhadap data-data tertulis, seperti buku figh klasik, buku figh kontemporer, artikel, jurnal, UU No 1 Tahun 1974, Kitab AlMabsuth karya Imam Abu Hanifah, Kompilasi Hukum Islam dan sumber tertulis lainnya yang berkaitan dengan kepemilikan harta dalam Islam melalui pewarisan. Sesuai dengan maksud tersebut, metode penulisan yang akan digunakan dalam penulisan artikel ini adalah metode deskriptif kualitatif. Adapun teknik pengumpulan data merupakam data sekunder dari berbagai buku, dokumen dan tulisan yang relevan untuk menyusun konsep penulisan artikel serta mengungkap obyek penelitian.

\section{HASIL PENELITIAN DAN PEMBAHASAN}

Asal kata "pembunuhan" ialah dari bentuk kata "bunuh", secara bahaasa memiliki arti habisi nyawa secara sengaja. Kemudian kata bunuh diberikan imbuhan berupa awalan pe-dan akhiran -an yang memiliki arti proses, cara, perbuatan membunuh. ${ }^{7}$

Didalam kamus bahasa Indonesia adalah sebuah usaha mencoba sesuatu; usaha hendak berbuat. ${ }^{8}$ Dari pengertian tersebut, dapat difahami bahwa arti pembunuhan dalam kategori percobaan terdapat dua pengertian;

Pertama, adanya suatu bentuk keinginan melakukan suatu tujuan tetapi ketika melakukan tidak sampai selesai. Dengan sebuah syarat adanya permulaan ketika bertindak, seperti contoh seorang anak ingin mengambil buah mangga, tetapi pada saat memanjat ternyata terlihat sang pemilik pohon, dan keinginan untuk mengambil buah mangga tersebut dikatakan sebagai percobaan.

${ }^{5}$ Hajar, hlm. 111.

${ }^{6}$ Hajar, hlm. 111.

${ }^{7}$ Kamus Besar Bahasa Indonesia (KBBI) Offline Versi 1.3.

${ }^{8}$ Moeljarno, Kitab Undang-Undang Hukum Pidana, cet. 28 (Jakarta: PT. Bumi Aksara, 2009), pp. 122-25. 
Drs. Adami Chazawi, S.H. mengutip sebuah kutipan dari Wijono Prodjodikoro yang mana umumnya kata percobaan dapat diartikan sebuah pencapaian tujuan karena adanya usaha, tetapi pada akhirnya belum tentu tercapai. Kemudian Drs. Adami Chazawi, S.H. mengutip sebuah kutipan dari Jonkers yang mengatakan adanya percobaan adalah sebuah bentuk usaha tetapi tidak sesuai tujuan akhirnya. Secara objektif konteks "usaha" seperti dalam kasus mencoba mengambil buah mangga wujud usahanya terdapat ketika ia memanjat sebuah pohon mangga, yang kemudian terhenti karena pemiliknya melihat.

Kedua, ada ungkapan "usaha mencoba sesuatu" yang merupakan sebuah kajian untuk menguji dalam bidang ilmu pengetahuan tertentu, seperti contoh memindahkan habitat ikan laut ke air tawar, dapat dimengerti dengan jelas sebagai kelinci percobaan. ${ }^{9}$

Namun dalam KUHP pasal 53 ayat 1, tentang mencoba kejahatan pidana yang dilakukan dengan cara percobaan, dengan meletakkan niat diawal pelaksanaan dan ternyata tidak terselsaikan karena semata-mata bukan atas keinginan sendiri. ${ }^{10}$ Dari pasal tersbut bukan lah sebuah penjelasan dari pegertian yuridis dari percobaan kejahatan, akan tetapi yang menjadi suatu rumusan tentang syarat pengeksekusian percobaan kejahatan, dapat dijatuhi pidana apabila:1.Terdapat sebuah niat, 2.Terdapat sebuah permulaan dalam tindakanya, 3.Tidak terselesaikan pelaksanaannya bukan sebab dirinya. ${ }^{11}$

Dalam KHI pasal 173 yang menjadi problem kewarisan adalah;

Seseorang terhalang menjadi ahli waris apabila dengan putusan hakim yang telah mempunyai kekuatan hukum yang telah, dihukum karena : a) Dipersalahkan telah membunuh atau mencoba membunuh atau menganiaya berat pada pewaris, b) Dipersalahkan secara memfitnah telah mengajukan pengaduan bahwa pewaris telah melakukan kejahatan yang di ancam dengan hukuman lima tahun penjara atau hukuman yang lebih berat $^{12}$.

Pembunuhan dapat diklasifikasikan dalam sebuah rumusan terminology fiqih; pembutuhan sengaja (al-qatl al-'amd) atau pembunuhan serupa dengan sengaja (al-qatl syibh al-'amd). Kemudian pada ayat b, memfitnah termasuk dalam kategori pembaharuan hukum waris dan resikonya lebih berat dibanding membunuh (Qs. alBaqarah (2); 191).

Adanya niat tersendiri menjadi sebuah perbedaan diantara perbuatan dengan aktivitas, antara sebuah kebiasaan dengan ibadah, antara susunan dalam sebuah ibadah dengan ibadah lainya.Demikian dalam hal tindak pidana, konteks niat merupakan sebuah pembeda diantara tindak pidana sengaja dan yang bersalah.

\footnotetext{
${ }^{9}$ Adami Chazawi, Pelajaran Hukum Pidana 3, Cet.5 (Jakarta: Rajawali Press, 2014), hlm. 1-2.

${ }^{10}$ Moeljarno, hlm. 24-25.

${ }^{11}$ Chazawi, hlm. 7.

${ }^{12}$ Undang-Undang Republik Indonesia Nomor 1 Tahun 1974 Tentang Perkawinan Dan Kompilasi Hukum Islam, 2nd edn (Yogyakarta: Pustaka Yustisia, 2009), hlm. 119.
} 
Di Pengadilan Agama sendiri, pelaku tindak idana tidak bisa dihukum ketika dia hanya berniat tanpa ada bukti perbuatan kejahatannya.Sebagai bentuk bukti daripada niatnya tersebut ketika dia melakukan perbuatan secara sengaja dengan tujuan menghilangkan nyawa. Diperlukannya bentuk pendukung sebagai bukti ia benar-benar membunuh dengan memperlihatkan alat yang digunakan untuk membunuh korban. Oleh karenanya pembunuhannya bisa dikategorikan pembunuhan sengaja ketika melihat alat yang digunakan untuk membunuh yang mana adalah alat secara umum untuk mematikan. ${ }^{13}$

Seperti halnya yang sudah dijelaskan, dalam hukum Islam ditetapkan bahwa pembunuhan bentuk penghalang mendapatkan kewarisan.Tetapi didalam KHI tersendiri penjelasannya diperlebar pada konteks percobaan pembunuhan.Adanya pelebaran dikarenakan adanya sebuah pertimbangan dalam bentuk penghalang kewarisan dalam KHI untuk menolak mudharatan didalamnya dan bentuk implikasinya pada hukum kewarisan. Kontek percobaan pembunuhan bisa dianggap tindak pidana ketika dia memiliki niat, kemudian persiapan dan pelalsanaan yang tidak bisa sampai pada tujuannya. Semua unsur itu termasuk dalam kategori menghalangi kewarisan karena sebuah tindakan piadna yang sempurna setiap tahapnya, apabila secara jelas terbukti adanya maksiat dan bertujuan membunuh. ${ }^{14}$

Dikalangan para Ulama Madzhab bersepakat ada tiga (3) hal yang menghalangi untuk mendapatkan harta warisan; perbudakan (al-riq), pembunuhan (al-qatl), dan berbeda agama (ikhtilaf al-din).Diberikannya sanksi dengan tegas tidak mendapatkan harta warisan yang mana sesuai kesepakatan Para Ulama bahwa pewaris yang terbunuh ahli warisnya secara sengaja atau bentuk direncanalan.Dalam keumuman sebuah hadits menggunakan dasar hukum:

$$
\begin{aligned}
& \text { أخبرنا على بن حجر بن إياس المروزي قال : ثنا إساعيل بن عياش عن ابن جريح و يهيى بن سعيد و ذكر آخر ثلاثتهم عن }
\end{aligned}
$$

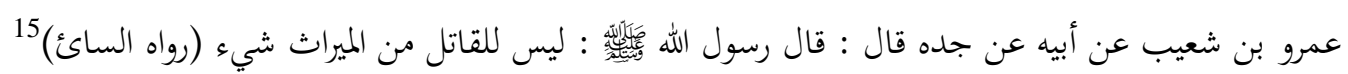

Telah meriwayatkan kepada kita Ali bin Hajr bin Iyas al-Maruzi berkata: berkata kepada kita Ismail bin 'Ayasy bin Ibn Juraij dan Yahya bin Said dan tiga dari mereka yang lain menyebutkan dari 'Umar bin Syu'aib dari bapaknya dari kakeknya berkata : Rasulullah saw Bersabda : "Tidak ada hak bagi pembunuh sedikitpun untuk mewarisi. (HR.Al-Nasa'i)

Adapun alasan dari para Ulama bahwa adanya jalan kekerasan yang digunakan ahli waris untuk mendapatkan harta warisan dari pewarisnya.Yang berakibat dia harus dijatuhi hukuman hilangnya hak darinya untuk memiliki harta warisan. Kaidah fiqh yang sesuai dengan keadaan tersebut adalah;

\footnotetext{
${ }^{13}$ Fauzan, hlm. 46.

${ }^{14}$ Fauzan, hlm. 47.

${ }^{15}$ Al-Imam Abi Abd al-Rahman Ahmad bin Syu'aib Al-Nasa'i.
} 
Riyan Ramdani, M. Najib Karim, Penganiayaan Berat sebagai Alasan Penghalang Mewarisi ...

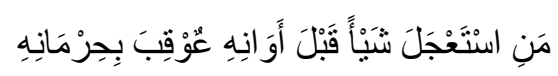

Seseorang akan tersiksan ketika tidak mendapatkannya dengan cara terburu-buru pada saat mendapatkannya. ${ }^{16}$

Dikutip sebuah kutipan dalam kitab al-Mabsuth karya Imam Abu Hanifah perihal hak waris untuk pembunuh ${ }^{17}$ :

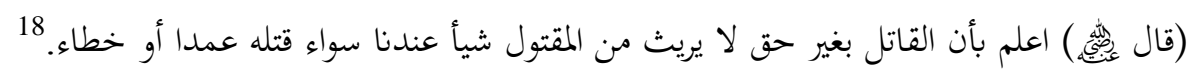

Berkata Imam Abu Hanifah ; Ketahuilah bahwasanya pembunuh tidak berhak mendapatkan warisan dari seseorang yang ia bunuh baik di bunuh secara sengaja atau tidak sengaja.

Sesuai dengan penjelasan diatas, Imam Abu Hanifah dalam pendapatnya merupakan tidak bisa mendapatkan harta warisan dari pembunuh yang membunuh pewarisnya walausecara unsur sengaja ataupun pembunuhan yang salah, pendapat dari Imam Abu Hanifah sendiri masih bisa dikategorikan masih bersifat umum. Tidak ada perbedaan diantara pembunuhan secara sengaja maupun tidak menurut Imam Abu Hanifah, tidak bisa mewarisi karena keduanya sama-sama dilakukan tanpa adanya suatu hak yang diperbolehkan oleh syara' .

Terdapat dua kategori yang diklasifikasikan oleh Imam Abu Hanifah, adanya pembunuhan karena ada unsur hak dan pembunuhan tanpa hak, sedangkan macamnya pembunuhan adanya pembunuhan sengaja dan tidak sengaja.

Imam Abu Hanifah menegaskan secara tegas tanpa adanya suatu hak dalam berbuat pembunuhan akan menyebabkan terhalang mendapatkan harta waris, ketika dilakukan secara sengaja maupun tidak. Dan kemudian Imam Malik mengomentari Imam Abu Hanifah, ketika seorang pembunuh ternyata membunuh secara tidak sengaja, maka pelaku tetap bisa menerima haknya mendapatkan harta waris dari pewaris yang dibunuhnya, tetapi tidak bisa mewarisi diyatnya. Kemudian ketika membunuh secara sengaja, si pembunuh tidak bisa menerima harta warisannya, dasar alasanya:

$$
\text { روى أن النبي صلى الله عليه و سلم قضى بأن لا ميراث للقاتل }
$$

Diriwayatkan dari Nabi saw ; di tetapkannya tidak mewarisi karena pembunuhan.

Dan hadits riwayat dari Umar ra.

$$
\text { عن عمر رضي الله عنه قال لا مير اث لقاتل }
$$

Dari Umar RA berkata tidaklah mewarisi melainkan karena pembunuhan.

Dan hadits riwayat dari Ubaidah al-Salmaniy ra

$$
\text { عن عبيدة رضي الله عنه لا مير اث لقاتل بعد صاحب البقرة بعنى بقرة بنى إسر ائيل }
$$

\footnotetext{
${ }^{16}$ A.Djazuli.

${ }^{17}$ Kitab al-Mabsuth merupakan kumpulan pendapat atau penjelasan Imam Abu Hanifah terhadap hukum-hukum fiqh yang disusun oleh Syamsuddin al-Sarkhasiy

${ }^{18}$ Syamsuddin Al-Sarkhasiy, Kitab Al-Mabsuth Juz 30 (Beirut: Dar al-Ma'rifah), hlm. 46-47.
} 
Dari 'Ubaidah RA tidaklah mendapat harta waris karena membunuh setelah pemilik sapi, yakni sapi bani israil.

Setiap pembunuh yang dilakukan dengan adanya suatu maksud untuk mendapatkan harta warisan akan kembali kepada hukum asalnya. Walaupun hanya adanya permulaan perencanaan tindak pembunuhan sengaja, sesuai hukumanya, keharaman untuknya memiliki harta warisan, sesuai makna pembunuhan sengaja.

Imam malik berpendapat terkait pembunuhan secara tidak sengaja, tidak adanya keinginan memiliki harta dari pewaris da tidak pula memiliki hasrat untuk membunuhnya. Pelaku pembunuhan secara tidak sengaja ini diberikan maaf dan tidak patut untuk dihukum, karena kesalahannya adalah belas kasih dari syara', dan tidak bisa dijadikan sebuah bukti untuk mencabut hak warisnya.Terkecuali dalam warisan diyat.Si pelaku tidak bisa mewarisi diyat dikarenakan adaya tanggungan membayar diyat. Karenanya tidak mungkin dia terbebani tanggungan untuk mewarisi diyat yang dibayarkannya.. ${ }^{19}$

Jaih Mubarok menyatakan bahwa Syariat sederhananya dapat dibedakan menjadi dua bagian, pertama, syariat sempurna yang diabadikan dalam alQuran dan Sunnah yang difungsikan sebagai penetap hukum, secara persoalan yang sudah terjadi maupun belum. Adanya perkembangan zaman dan tuntutan zaman (alsyariat shalih lii kulli zaman wa almakan) menjadi sebuah syariat yang diyakini. Kedua,proses istinbath suatu hukum berupa ijtihad yang menjadi sebuah ketetapan hukum,ijtihad tersendiri memiliki sifat yakni relative karena bisa berubah seuai zamannya. Ada dua kaidah yang ditetapkan para Ulama: ${ }^{20}$

$$
\text { تغير الفتوى بحسب تغير الأزمنة والأمكنة والأحوال والنيات والعوائد }
$$

Berubahnya zaman, tempat, keadaan, niat, maupun adat kebiasaan bisa merubah suatu fatwa.

Dalam konteks ini Kompilasi Hukum Islam menggunakan tiga metode ushul fih dalam menentukan pembaharuan penghalang kewarisan, pertama, maslahah mursalah, kedua, sad dzariah, ketiga, qiyas.

Maslahah dari sisi ada dan tidak ada dalilnya terbagi tiga yaitu Maslahah Mu'tabarah, yaitu bentuk kemaslahatan yang secara argumentasi ada pada al - Qur'an dan al - Sunnah.Maslahah Mulghah ialah maslahah yang menurut akal dianggap baik sedagkan menurut syariat tidak dikehendakibahkan ada argumentasi hukum agama yang menolaknya.Maslahah mursalah ialah bentuk maslahah atau bentuk kemanfaatan yang secara argumentasinya tidak ada pada alQu'ran maupun hadits baik yang di bolehkan atau yang dilarang. Penelis memiliki hipotesa bahwa dalam hal ini Kompilasi Hukum

\footnotetext{
${ }^{19}$ Al-Sarkhasiy, hlm. 46-47.

${ }^{20}$ Jaih Mubarok, Hukum Islam (Bandung: Benang Merah Press, 2006), hlm. 90-91. 
Islam menggunakan Maslahah mursalah: bahwa dengan memasukan fitnah sebagai penghalang menerima waris, Kompilasi Hukum Islam memandang baik terhadap hal ini. Karena bahaya dari akibat yang akan ditimbulkan oleh fitnah tersebut.

Sad adz - dzariah: dengan menggunakan metode ushul fiqh ini Kompilasi Hukum Islam mencegah sebelum terjadinya pembunuhan maka hal apa saja yang akan mendekati terhadap pembunuhan itu sudah di antisipasi, oleh karena itu Kompilasi Hukum Islam memasukan percobaan pembunuhan, penganiayaan berat dan fitnah. Karena jika dilihat secara akibat maka muara nya aka kepada kematian, seperti penganiayaan berat yang akan melukai pisik korban apalagi jika percobaan pembunuhan yang sudah ada niat. Disini fitnah juga di masukan karena memiliki efek jera hukuman minimal lima tahun bahkan lebih.

Rukun qiyas ada 4, yaitu al-ashlu, al far'u, hukum ashal, illat.Qiyas: Kompilasi Hukum Islam memasukan qiyas sebagai metodeologi ini karena menyamakan antara pmbunuhan dengan fitnah, sebab ada alasan yang sama pada Illat nya yaitu dengan cara ingin cepat - cepat mendapatkan warisan.

Disastu sisi Kompilasi Hukum Islam ini dalam memasukan pengahalang waris dengan mengadopsi dari hukum perdata, tetapi pengadopsian ini bukan secara Cuma Cuma tetapi ada penggalian hukum secara metodelogi ushul fiqh.

Disini penulis akan membahas tentang relevansi Terhalang Kewarisan Karena Fitnah menurut Ushul Fiqh KHI Terhadap Pembaharuan Hukum Islam.Bahwa telah diuraikan di atas, kompilasi Hukum Islam menggunakan tiga metodelogi Ushul Fiqh yaitu, maslahah mursalah, sad adz - dzariah, dan qiyas.

Adapun metode yang digunakan sebagai Tolak ukur relevansinya penulis menyandingkan dengan metode Intra-doctrinal Reform dan Extra-doctrinal ReformIntradoctrinal Reform yaitu pembaharuan hukum Islam yang berdasarkan pada madzhab fiqh yang di anutnya pada sebuah Negara, seperti Indonesia yang lebih didominasi oleh penganut madzhab Syafi'i. sehingga cara yang digunakan pada metode intra-doctrinal reform ini yaitu, dengan menggunakan takhyir (memilih salah satu pandangan madzhab fiqh, walupun ulama luar madzhabnya), atau bisa juga disebut tarjih, selanjutnya yaitu talfiq (menggabungkan pendapat para ulama).

Metode Extra-doctrinal reform merupakan metode dimana Negara muslim dalam melakukan pembaharuan hukum Islam keluar dari pendapat madzhab fiqh yang di ikutinya. Dengan metode extra-doctrinal reform ini mereka melakukan ijtihad yang baru.Dengan menggunakan Sadd al - dhariah, maslahah mursalah, regulatori dan administrasi. ${ }^{21}$

Di lihat pada metode pembaharuan hukum, Kompilasi Hukum Islam Menggunakan dua metode, yaitu Intra-doctrinal Reform, karena masih mengambil rujukan

${ }^{21}$ Khoeruddin Nasution, Hukum Keluarga Perdata Islam Indonesia, hlm.44.

Al-Ahwal Al-Syakhsiyyah : Jurnal Hukum Keluarga dan Peradilan Islam 105 
refensi pembahasan pada kitab kitab bermadzhab syafi'I, kemudian Kompilasi Hukum Islam pun menggunakan metode Extra-doctrinal refor, karena Kompilasi Hukum Islam secara ushul Fiqh menggunakan Maslahah Mursalah, sad Adz Dzariah dan qiyas. Maka penulis berkesimpulan bahwa hal - hal yang menghalangi waris seperti fitnah dengan metode penggalian Ushul Fiqh maslahah mursalah, sad adz - dzariah dan qiyas sangat relevan dengan pembaharuan hukum Islam.

Hal baru dimana ulama terdahulupun belum ada yang mencetuskan secara teksual bahwa hal yang menghalangi waris itu yaitu, percobaan pembunuhan, penganiaayaan berat, dan fitnah.Tetapi dengan adanya ijtihad baru dalampenanganan penghalang aris yang sudah dtentukan oleh Negara lewat Kompilas Hukum Islam, ini menandakan bahwa ijtihad dalam hal penghalang kewarisan itu sesuai dengan kebutuhan saat ini.

Maka penulis memiliki hipotesis bahwa hal - hal yang menghalangi waris seperti fitnah dengan metode penggalian Ushul Fiqh maslahah mursalah, sad adz- dzariah dan qiyas sangat relevan dengan pembaharuan hukum Islam.Menganiaya merupakan seubuah perlakuan dengan sewenang-wenangnya (seperti menyiksa, menyakiti).Adapun peganiayaan berat ialah cacatnya badan atau kematian yang diakibatkan perbuatan kekerasan secara disengaja kepada seseorang. ${ }^{22}$

Sebagaimana alQuran pada surah al-A'raf ayar 33:

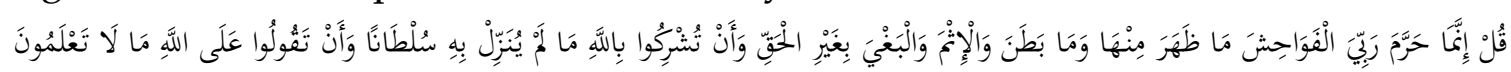

Katakanlah: "Tuhanku hanya mengharamkan perbuatan yang keji, baik yang nampak ataupun yang tersembunyi, dan perbuatan dosa, melanggar hak manusia tanpa alasan yang benar, (mengharamkan) mempersekutukan Allah dengan sesuatu yang Allah tidak menurunkan hujjah untuk itu dan (mengharamkan) mengada-adakan terhadap Allah apa yang tidak kamu ketahui."

Pada penjelasan ayat diatas, Allah SWT mengharamkan segala bentuk dosa, baik besar atau kecil.Baik perbuatannya keji, bentuk aqad yang berbeda dengan kehendak syara', dan ucapan yang salah serta bentuk I'tikad yang batal.Dalam ayat ini terkumpul segala yang haram. ${ }^{23}$

Lalu pada surah an-Nahl ayat 90:

Sesungguhnya Allah menyuruh (kamu) Berlaku adil dan berbuat kebajikan, memberi kepada kaum kerabat, dan Allah melarang dari perbuatan keji, kemungkaran dan permusuhan. Dia memberi pengajaran kepadamu agar kamu dapat mengambil pelajaran.

Pada penjelasan ayat ini, sebuah keterangan inti kejahatan yang dijadikan sumber sebuah kebaikan.Sebagaimana Umar Ibn Abdul Aiz yang menggunakan ayat ini pada

${ }^{22}$ 'Www. Arti Kata.Com'. diakses ada tanggal 04 Juni 2019 jam 22.56

${ }^{23}$ Hasbi Ash Shiddieqy, Tafsir Al-Bayaan I (Yogyakarta: T. Al-Maarif Bandung, 1966). 
akhir khutbahnya.Sebagai pengganti untuk mengejek sayyidina Ali yang dikerjakan oleh para khatib bani Umayah. ${ }^{24}$

Dari keterangan diatas penganiayaan berat merupakan sesuatu perilaku kedzaliman yang allah benci, berbicara hal kewarisan tindak penganiayan berat ini mengakibatkan kecacatan pada korban atau mengakibatkan kematian. Karena itu didalam KHI dirumuskan bahwa penganiayaan berat termasuk perbuatan keji serta termasuk dosa besa terhadap pelakunya.

Sebuah bentuk hipotesis yang penulis sadari bahwa pelaku penganiayaan berat sangat pantas dihukum, tidak menerima waris. Adapun sebuah uraian dari pemikiran penulis seperti ini; pertama, dririwayatkan adri Imam Ahmad, suatu petunjuk mengenai pembunuhan yang menghalangi waris karena beberapa hal sesungguhnya ai telah berkata dalam sebuah riwayat anaknya salih dan Abdullah, menunjukkan segala bentuk pembunuhan menghalangi pewarisan. Dan ini terasuk pendapat madzhab syafi' i. $^{25}$

Di asumsikan bahwa setiap keadaan pembunuhan tetap akan mendapatkan sanksi membunuh seseorang tidak akan menerima waris. Baik ketika kondisi langsung maupun tidak langsung, sadar atau tidak sadar, da bentuk lainnya. Demikian juga dengan "cara", maka dengan cara bagaimanapun pembunuhan itu dilakukan juga tetap dihukum tidak mewarisi dari orang yang dibunuh, misalnya saja dengan cara langsung, atau tidak langsung (dalam hal ini dengan penganiayaan berat) dengan cara memenggal leher sehingga orang tersebut meninggal seketika, atau dengan cara memukul, mengikat, memenjarakan sehingga mengakibatkan kematian secara perlahan-lahan, serta agak tertunda. Semua bentuk pembunuhan tersebut dinyatakan tidak mewarisi. Dengan demikian, pengertian pembunuhan tersebut bisa mencakup makna pembunuhan dengan cara menganiayaa, karenanyaorang yang memfitnah tersebut dinyatakan tidak mewarisi dari orang yang difitnahnya.

Kedua, sebuah kesimpulan yang penulis dapat dari alBaihaqi bahwa konteks penganiayaan berat termasuk bentuk penghalang kewarisan sesuai ungkapan dari beliau, beberapa pembahasan yang di kemukakan alBaihaqi bahwa orang yang membunuh secara mutlah tidak dapat menerima hak wari. ${ }^{26}$

Ketiga, pendapat ulama mengutarakan bahwa pembunuhan yang masih berbentuk niat dalam artian ingin mempercepat memperoleh harta warisan itu juga termasuk pada pembunuhan yang dapat menghalangi waris.

Dalam sebuah riwayat dari Imam al-Nawawi mengatakan suatu pendapat yang shahih bahwa segala bentuk keadaan orang yang melakukan tindak pembunuhan tidak akan mewarisi. Merujuk kepada sabda Nabi SAW yang diriwayatkan oleh Ibnu Abbas

\footnotetext{
${ }^{24}$ Hasbi Ash Shiddieqy, . hlm.739.

25Pagar, Pembaharuan Hukum Islam Indonesia, hlm. 141.

26Pagar, Pembaharuan Hukum Islam Indonesia, hlm. 142.
}

Al-Ahwal Al-Syakhsiyyah : Jurnal Hukum Keluarga dan Peradilan Islam 107 
RA; "tercegahnya seseorang yang membunuh karena suatu keinginan untuk mendapatkan harta waris, dan wajib pula untuk mencegah kepada pembunuh dengan berbagai tindakan dan keadaan untuk menutup kesempatan.

Senada dengan pendapat tersebut Wahbah al-Rakhili mengatakan bahwa:

$$
\text { المراث قبل او انفها على ان القتل مانع من الميراث فالقا تل لايرث من قتيله لقوله صلى الله عليه و سلم : ليس لقاتل ميراث استعجل }
$$

Fuqaha bersepakat hal yang mengahalangi kewarisan yaitu pembunuhan, yang dikuatkan dengan sabda Rasul SAW “Tidak diwarisinya, orang yang membunuh” karena adanya perbuatan yang dilarang maka ia harus dihukum tidak mendapatkan harta waris, karena ada sebuah maksud, yang mana dengan suatu penyebab membawa sebuah kerusakan. Sungguh orang yang melakukan perbuatan kerusakan Allah SWT tidak menyukainya.

Dalam sebuah kutipan "perbuatan yag dilarang" sifatnya masih umum, adapun perbuatan pembunuhan dengan memfitnah terkategorikan sebuah perbuatan yang dilarang.Pantaslah poin memfitnah di masukan dalam penghalang kewarisan.

Walaupun secara tekstual kata penganiayaan tidak dimasukan sebagai bentuk penghalang waris, tetapi setelah penulis menelaah apa yang dijelaskan diatas bahwa penganiayaan berat dapat diberlakukan.

Masyarakat Indonesia seringkali mengucapkan kata aniaya atau menganiaya. Dalam bahasa Indonesia, kata aniaya seperti disebutkan banyak kamus Indonesia adalah: perbuatan bengis (seperti penyiksaan, penindasan).

Penghalang kewarisan merupakan bentuk tindakan ataupun beberapa hal gugurnya seseorang memperoleh hak waris.

Ulama Faraidh megistilahkan konteks penghalang harta pusaka:

"keadaan yang disebabkan tidak bisa mendapatkan pusaka, sedangkan cukup adanya sebab dan syarat." 27

Adapun penghalang kewaris merupakan suatu kondisi pada seseorang yang harus memenuhi beberapa sebab dan syarat dapat memperoleh harta yang disebabkan terhalang untuk mendapatkannya. ${ }^{28}$

\section{Simpulan}

Dalam buku Kompilasi Hukum Ilsam tidak diberikan pengertian yang jelas dan konkrti tentang apa yang dimaksud dengan penganiayaan berat. Imam Hanafi berpendapat bahwasanya pembunuhan tidak berhak mendapatkan warisan dari seseorag yang ia bunuh baik dibunuh secara sengaja atau tidak sengaja. Oleh karena itu beberapa

27T.M. Hasbi Ash Shiddieqy, hlm. 37.

${ }^{28}$ Rahman, hlm. 83. 
hal yang penting dan belum memperoleh tekanan dalam pengkajian Kompilasi Hukum Islam agar memperoleh kejelasan, maka haruslah mengemukakan dasar hukum atau dalil nash atau ijtihad yang mendukung ketentuan qiyas.

Dalam konteks ini Kompilasi Hukum Islam menggunakan tiga metode ushul fiqh dalam menentukan pembaharuan penghalang kewarisan, pertama, maslahah mursalah, kedua, sad dzariah, ketiga, qiyas.Maslahah mursalah: bahwa dengan memasukan fitnah sebagai penghalang menerima waris, Kompilasi Hukum Islam memandang baik terhadap hal ini. Karena bahaya dari akibat yang akan ditimbulkan oleh fitnah tersebut. Sad adzdzariah: dengan menggunakan metode ushul fiqh ini Kompilasi Hukum Islam mencegah sebelum terjadinya pembunuhan maka hal apa saja yang akan mendekati terhadap pembunuhan itu sudah di antisipasi, oleh karena itu Kompilasi Hukum Islam memasukan percobaan pembunuhan, penganiayaan berat dan fitnah. Karena jika dilihat secara akibat maka muara nya aka kepada kematian, seperti penganiayaan berat yang akan melukai pisik korban apalagi jika percobaan pembunuhan yang sudah ada niat. Disini fitnah juga di masukan karena memiliki efek jera hukuman minimal liam tahun bahkan lebihQiyas: Kompilasi Hukum Islam memasukan qiyas sebagai metodeologi ini karena menyamakan antara pmbunuhan dengan fitnah, sebab ada alasan yang kuat yaitu dengan cara ingin cepat - cepat mendapatkan warisan.

Hubungan antar pasal dengan pendapat para ulama bahwasanya pengelompokkan penghalang waris dalam KHI pasal 173 adalah pembaharuan hukum waris sesuai dari sebuah kaidah "Hukum bisa berubah sesuai dengan keadaan tempat dan waktu", dan diharapkan adanya sosialisasi dari pemerintah terkait penghalang kewarisan agar masyarakat mengetahuinya.

\section{DAFTAR PUSTAKA}

Al-Nasa'i, Al-Imam Abi Abd al-Rahman Ahmad bin Syu'aib, No Title

Al-Sarkhasiy, Syamsuddin, Kitab Al-Mabsuth Juz 30 (Beirut: Dar al-Ma'rifah)

Chazawi, Adami, Pelajaran Hukum Pidana 3, Cet.5 (Jakarta: Rajawali Press, 2014)

Fauzan, Percobaan Pembunuhan Sebagai Penghalang Kewarisan, Dalam Al-Hurriyah, Vol. XI, No.1

Kamus Besar Bahasa Indonesia (KBBI) Offline Versi 1.3.

M, Hajar, Dimensi Hukum Kewarisan Islam Di Indonesia, 1st edn (Pekanbaru, 2008)

Moeljarno, Kitab Undang-Undang Hukum Pidana, cet. 28 (Jakarta: PT. Bumi Aksara, 2009)

Mubarok, Jaih, Hukum Islam (Bandung: Benang Merah Press, 2006)

Pagar, Pembaharuan Hukum Islam Indonesia (Bandung: Cita Pustaka, 2007) 
Rahman, Fathur, Ilmu Waris, 1st edn (Bandung: PT Al-Ma'arif, 1975)

Shiddieqy, Hasbi Ash, Tafsir Al-Bayaan I (Yogyakarta: PT. Al-Maarif Bandung, 1966)

Shiddieqy, T.M. Hasbi Ash, Fiqhul Mawaris, Cet. 1 (Jakarta: PT. Bulan Bintang, 1973)

Undang-Undang Republik Indonesia Nomor 1 Tahun 1974 Tentang Perkawinan Dan Kompilasi Hukum Islam, 2nd edn (Yogyakarta: Pustaka Yustisia, 2009)

'Www. Arti Kata.Com' 